\title{
Kış Yoğurdu
}

\author{
Şenol KÖSE ${ }^{1}$
}

ÖZET: Kış yoğurdu ülkemizin Van, Sivas, Hatay illeri ile Akdeniz Bölgesinin bazı illerinde daha çok küçük işletmelerde ve kırsal kesimde yaşayan aileler tarafindan geleneksel yöntemlerle üretilen konsantre bir yoğurt çeşididir. Bu yoğurt değişik bölgelerimizde; tuzlu yoğurt, güz yoğurdu ve pişmiş yoğurt adıyla bilinmektedir. Kış yoğurdu genellikle, Van ili çevresinde koyun sütü veya koyun sütü ile inek sütü karışımından üretilmektedir. Bu yoğurdun üretimi bölgelere göre değiş̧iklik göstermektedir. Bu çalışmada kış yoğurdunun üretimi, bileşimi ve mikrobiyolojik özellikleri üzerine yapılan araştırmalar derlenmiştir.

Anahtar Kelimeler: Kış yoğurdu, üretim teknolojisi, kimyasal bileşimi, mikrobiyolojik özellikleri

\section{Winter Yoghurt}

\begin{abstract}
Winter yoghurt is a kind of concentrated yoghurt, traditionally produced in small plants and by the people who live in urban locations in some province of the Mediterranean region and Van, Sivas, Hatay province of Turkey. This yoghurt is known as salted yoghurt, fall yoghurt and cooked yoghurt in our different regions. Winter yoghurt is manufactured using sheep milk or the mixture of sheep and cows milks in around of Van province. According to regions, production of this yoghurt can change. In this study, researches on the production, composition and microbiological properties of winter yoghurt were reviewed.
\end{abstract}

Keywords: Chemical compounds, microbiological properties, production techniques, winter yogurt

Şenol KÖSE (0000-0003-0599-6030), Van Yüzüncü Yıl Üniversitesi, Mühendislik Fakültesi, Gıda Mühendisliği, Süt Teknolojisi, Van, Türkiye

Sorumlu yazar/Corresponding Author: Şenol KÖSE, senolkose28@gmail.com 


\section{GİRIŞ̧}

Yoğurt, sütün laktik asit fermantasyonuna tabi tutulmasıyla elde edilen ve laktik asit bakterilerini canlı olarak ihtiva eden besin değeri yüksek fermente bir süt ürünüdür. Türk Gıda Kodeksi, Fermente Sütler Tebliği'nde yoğurt; fermentasyonda spesifik olarak Streptococcus thermophilus ve Lactobacillus delbrueckii subsp. bulgaricus'un simbiyotik kültürlerinin kullanıldığ fermente süt ürünü şeklinde tanımlanmaktadır (Anonim, 2009; Güven ve ark., 2009).

4000 yıl önce ilk defa Türkler tarafından yapılan yoğurt, Avrupa'da 20. yüzyılın başlarından itibaren, Amerika'da da yaklaşık 70 yıldır tanınmaya ve üretilmeye başlanmıştır. Bugün ise bütün dünya ülkelerinde üretilip tüketilmektedir (Gönç, 1989). Yoğurt, özellikle Türkiye'de çok fazla tüketilen bir süt ürünüdür. Besin değeri üstündür ve sindirimi kolaydır. Çeşitli şekillerde sulandırılıp ayran haline getirilerek, bazen sarımsak v.s katılarak, bazen de serum kısmı uzaklaştırılıp daha konsantre hale getirilerek tüketime sunulmaktadır. Çocukların ve hastaların; özellikle sindirim bozukluğu çekenlerin başlıca besin kaynağı olan yoğurt, çeşitli çorbaların yapımında ve tarhananın hazırlanmasında da kullanılabilmektedir (Yöney, 1974). Bu üstün özellikleriyle yoğurt; Türk halkının milli bir yiyeceği olmuş, her mevsimde, her ailenin evinde eksik olmayan ve her yaştaki insanın severek, güvenerek kullandığ bir süt ürünü haline gelmiştir (Sakız, 1973).

Beslenmemizde önemli bir yeri olan yoğurdun kişi basına tüketimi yılda $35.19 \mathrm{~kg}$ düzeyindedir. Bu değer Fransa'da 35, Almanya'da 34.63, Hollanda'da 35.70 ve ABD'de 7.70 kg'dır (Anonymous, 2013).

Başta yoğurt olmak üzere fermente süt ürünlerinin insan beslenmesi açısından önemi arttıkça, yoğurt tüketimi ve buna bağlı olarak da üretimi artmaktadır. Ülkemizde üretilen sütün yaklaşık \%23'ü yoğurda işlenmektedir (Yaygın, 1993).

Yoğurt, yapım ve depolamaya bağlı olarak belli bir süre sonra yapısı bozulmakta, ekşimekte ve tüketilemeyecek duruma gelmektedir. Bunun sebebi de içerdiği yaklaşık \%85 oranındaki sudur. $\mathrm{Bu}$ durumu dikkate alan ve özellikle sıcak iklim bölgelerinde yaşayan toplumlar, daha uzun raf ömrüne sahip konsantre yoğurt çeşitlerini üretmeye başlamışlardır (Uysal, 1993).

Bugün yurdumuzun birçok bölgesinde özellikle hayvancılığın yaygın olarak yapıldığı kırsal kesimde değişik adlarla çeşitli konsantre yoğurt üretimi gerçekleştirilmektedir. Yurdumuzda konsantre yoğurtlar, farklı yollarla yoğurdun suyunun bir miktar uzaklaştırılması ile üretilmektedir (Yaygın, 1970).

Ülkemiz dışında da konsantre edilmiş fermente süt ürünleri yapılmaktadır. Bunlar özellikle sıcak iklime sahip olan Arap ülkeleri, Hindistan, İsrail, Yunanistan ve ayrıca İzlanda'da önemli miktarda üretilmektedir. Konsantre edilmiş süt ürünleri Lübnan ve bazı Arap ülkelerinde "Labneh" veya "Lebneh", İsrail'de "Labneh Anbaris", Misır'da "Leben Zeer", Hindistan' da "Chakka" ve "Shirkland", İzlanda'da "Skyr" adiyla anılmaktadır ( Uysal, 1993; Eren, 2002).Günümüzde toplumumuzun beslenmesinde önemli yer tutan konsantre yoğurt çeşitlerinden en önemlileri; Torba yoğurdu, Kış yoğurdu, Kurut, Tulum yoğurdu ve Silivri yoğurdudur ( Uysal, 1993; Özdemir ve ark., 1995).

Ülkemizde kış yoğurdu; tuzlu yoğurt, tutma yogurt, güz yoğurdu ve pişmiş yoğurt gibi değişik adlarla bilinmektedir. Bu yoğurt özellikle Van, Sivas, Hatay illeri ile Akdeniz Bölgesinin bazı illerinde üretilip tüketilen raf ömrü uzun bir yoğurt çeşididir (Gökalpay, 1965; Gönç ve Oktar, 1973; İnal, 1990). Yani kendi haline bırakıldığında birkaç gün dayanmayan yoğurt, ikinci kez işlenerek, bu arada bozulmasını kolaylaştıran suyu azaltılarak, pişirerek ve tuz katarak elde edilmektedir. Ayrıca bozulmada önemli bir faktör olan hava ile ilişkisini keserek dayanıklı hale getirilmektedir (Yöney, 1967).

Kiş yoğurdu koyun sütünün bol olduğu yaz mevsiminde yapılmakta ve sütün olmadığı kış aylarında farklı şekillerde tüketilmektedir. Kış yoğurdu çeşitli çorbaların ve börek yapımında kullanılmakta, çeşitli oranlarda sulandırılarak ayran olarak hazırlanıp tüketilmektedir. Ayrıca zeytinyağı ve baharatların ilavesi ile kahvaltılık olarak da kullanılmaktadır (Özrenk, 2004). 


\section{KIŞ YOĞURDU'NUN ÜRETIM TEKNOLOJISI}

Kiş yoğurdunun üretiminde uygulanan yöntemler, o bölgenin gelenek, göreneklerine ve yaşantıs1na bağlı olarak bazı değişiklikler gösterebilmektedir. Sivas ve Hatay yöresinde üretilen kış yoğurdunda daha çok keçi sütü kullanılmaktadır.

Öncelikle süt bir bez yardımıyla süzülerek yabancı maddelerinden ayrılmakta ve iyice pişirilmektedir. Bunu mayalama sıcaklığına kadar soğutma ve daha sonrada mayalanarak inkübasyona bırakma işlemleri izlemektedir. Elde edilen taze yoğurtlar temiz torbalar içerisine konularak gölgede yüksekçe bir yere asılmaktadır. En az 2, en çok 5 saat yoğurdun suyunun süzülmesi sağlanmaktadır. Ertesi gün, suyu süzülen yoğurtlara, kaybolan su kadar temiz soğuk su ilave edilerek pişirilmektedir. Pişirme 11,5 saat kadar devam etmekte ve daha sonra yoğurda \%1- 4 oranında tuz ilave edilerek 10- 15 dakika kadar daha pişirme işlemine devam edilmektedir. Pişirilen yoğurtlar, temiz, yayvan, kalaylı kaplara boşaltılarak soğutulmakta ve teneke, kavanoz veya içi sırlı çömleklere hava kalmayacak şekilde yerleştirilmektedir. Bu şekilde ambalajlanan yoğurtların üzerine sade yağ, iç yağ1 veya zeytin yağı dökülerek kışa kadar muhafaza edilebilmekte ve tüketilebilmektedir (Gönç ve Oktar, 1973; Köse, 2009; Tokatlı ve ark., 2012).

Gönç ve Oktar (1973), kış yoğurdunun Hatay ilinde sütün bol olduğu yaz aylarında yapılıp, kışın tüketilen geleneksel bir ürün olduğunu açıklamıştır.
Araştırmacılar yaptıkları çalışmada bu ürünün üretimi sırasında belirli bir yol izlenmemekle birlikte, genellikle taze yoğurdun süzme, pişirme, tuzlama ve çeşitli maddelerle stabilize etme işlemlerine tabi tutularak uzun süre saklanması esasına dayandığını belirlemişlerdir.

Van den Berg (1988), yaptığı çalışmada kış yoğurdunun ülkemizde keçi sütünden üretildiğini belirtmiştir. Araştırıcı bu ürünün yapılışını şöyle anlatmıştır; keçi sütünden elde edilen yoğurt, bez torbalarda asılıp yaklaşık 6 saat süreyle suyu süzüldükten sonra hafif ateş üzerinde suyunun bir kısmının daha uzaklaştırılması için tutulmaktadır. Yoğurdun kurumaddesi yaklaşık \%30 olduğunda bu işleme son verilmekte ve yoğurda \%2 civarın da tuz katılmaktadır. Daha sonra kış yoğurdu soğutularak kaplara konmakta ve hava ile temasının kesilmesi amacıyla üzeri bitkisel yağlarla örtülmektedir. $\mathrm{Bu}$ şekilde elde edilen kış yoğurdu sütün az olduğu kış aylarında tüketilmektedir.

Van ve çevre illerinde üretilen kış yoğurdunda ise pişirme ve tuzlama işlemleri yoktur. Hammadde olarak keçi sütü yerine koyun sütü kullanılmaktadır. Kaynatılıp soğutulan süt mayalanarak inkübasyona bırakılmakta ve oluşan yoğurt üzerine, bez serilerek suyunun alınması sağlanmaktadır. Daha sonra kaymak tabakası uzaklaştırılarak, yoğurdun oksijen ile temasını kesmek amacıyla üzerine eritilmiş tereyağ, sade yağ veya margarin dökülmektedir. Bu şekilde sütün ucuz ve bol olduğu zamanlarda yapılan k1ş yoğurdu, sütün az ve pahalı olduğu dönemlerde tüketilebilmektedir (Ocak, 1996; Köse, 2009). 


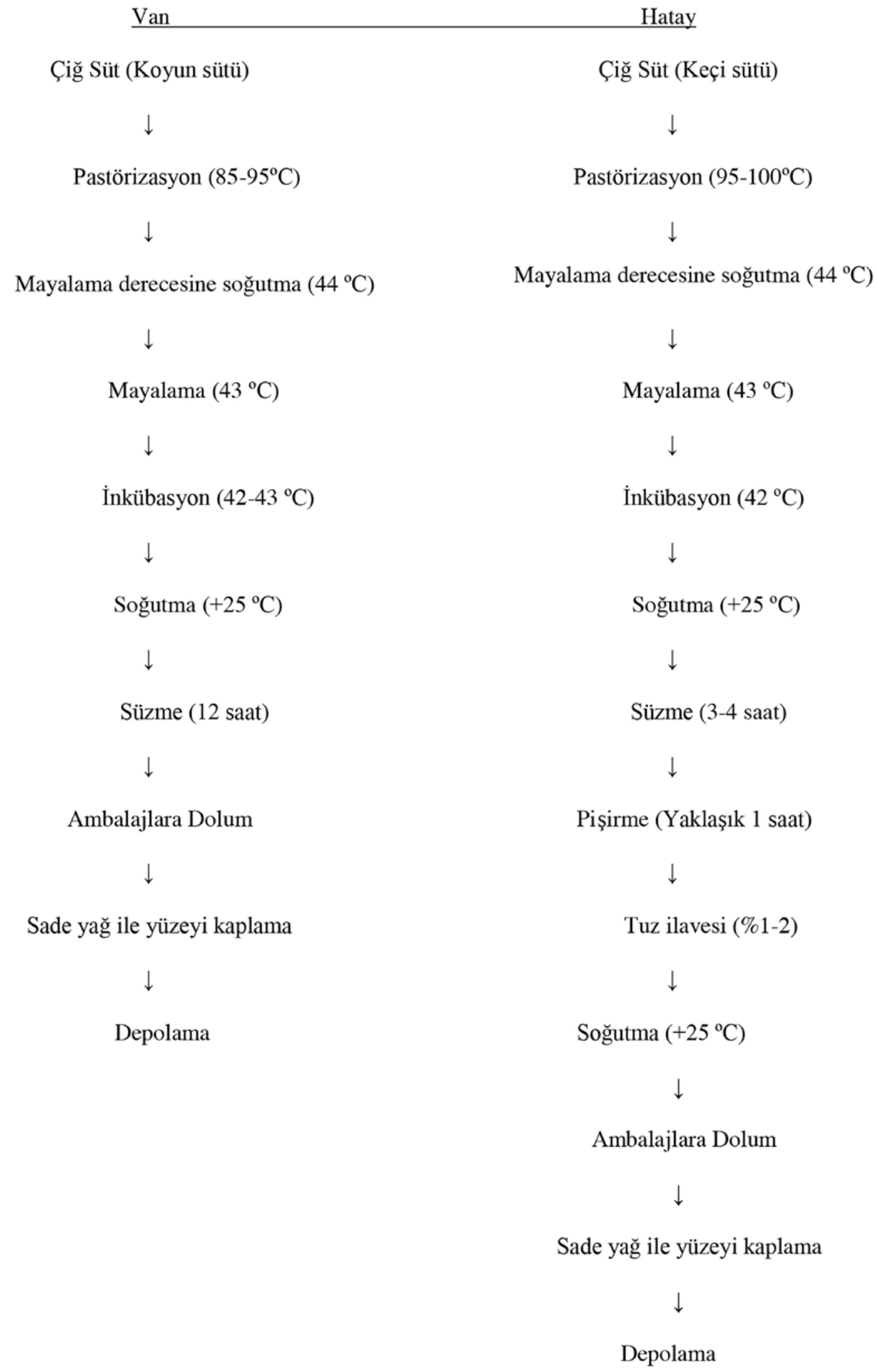

Şekil 1. Hatay ve Van yöresinde yapılan kış yoğurtlarının üretim akışşeması (Ocak, 1996; Say, 2001; Köse, 2009)

Böylece herhangi bir katkı maddesi ilave etmeden tamamen doğal yolla yoğurdun raf ömrü artırılmış olmaktadır (Köse, 2009). 


\section{KIŞ YOĞURDU'NUN BILLEŞİMI}

Ülkemizde üretim şartlarına bağlı olarak yoğurtların bileşimi önemli farklılıklar gösterir. Bu farklılık- ların daha iyi anlaşılabilmesi için üretimi yaygın olan yoğurt, süzme yoğurt, kış yoğurdu ve tuzlu yoğurdun kimyasal bileşimleri Çizelge 1'de verilmiştir.

Çizelge 1 . Türkiye'de üretilen bazı yoğurtlarımızın ortalama bileşimi (Köse, 2009)

\begin{tabular}{lccccccc}
\hline & $\begin{array}{c}\text { \%Kuru } \\
\text { madde }\end{array}$ & \%Yağ & \%Protein & $\begin{array}{c}\text { Asitlik } \\
\text { (\% 1.a) }\end{array}$ & pH & \%Kül & Kaynaklar \\
\hline Yoğurt & 10.86 & 2.93 & 3.38 & 1.25 & 3.68 & 0.67 & (Türkoğlu ve ark., 2003) \\
Süzme yoğurt & 21.64 & 6.58 & 8.25 & 2.01 & 3.63 & - & (Kırdar ve Gün, 2000) \\
Kış yoğurdu & 17.16 & 6.71 & 6.48 & 2.06 & 4.12 & 0.96 & (Ocak, 1996) \\
Tuzlu yoğurt & 25.29 & 8.98 & 10.04 & 2.03 & - & - & (Şahan ve Say, 1998) \\
\hline
\end{tabular}

Depolama süresi boyunca kış yoğurtlarında meydana gelen değişiklikleri inceleyen Köse (2009), homojenize sütlerden yapılan kış yoğurdu örneklerinde kurumadde de yağ, asitlik, lipoliz, proteoliz ve pihtı yapışkanlığ 1 değerlerinin, homojenize edilmemiş sütlerden yapılanlara göre daha yüksek olduğunu saptamıştır. Ayrıca koyun sütünden üretilen kış yoğurdu örneklerinin kurumadde, kül, asitlik, pH, pıhtı sıkılı̆̆ı, pihtı yapışkanlığı ve proteoliz değerlerinin, koyun+inek sütü karışımından üretilenlere göre daha yüksek olduğunu tespit etmiştir. Yine depolama süresince kış yoğurtlarında herhangi bir serum ayrılmasının gözlenmediğini saptamıştır.

Ocak ve Akyüz (1998), Van ili çevresinde 22 adet örnek alarak yaptıkları araştırmada kış yoğurdunun ortalama olarak \%17.16 kurumadde, \%6.71 yağ, \%10.45 yağsız kurumadde, \%38.96 kurumadde de yağ, \% 0,966 kül, \% 6.48 protein, \% 2.06 titrasyon asitliği ve 4.11 $\mathrm{pH}$ değerlerine sahip olduğunu belirlemiştir.

Hatay ilinde üretilen ve satışa sunulan tuzlu yogurtlardan 44 örnek üzerinde analizler yapan Şahan ve Say (1998), ortalama olarak pH'y1 3.66, titrasyon asitliğini $\% 2.03$, kurumaddeyi $\% 25.29$, yağı $\% 8.98$, proteini $\% 10.04$, laktozu $\% 1.43$, tuzu $\% 4.11$ olarak belirlemişlerdir.

İnek ve keçi yoğurtlarından süzerek ve süzmeden geleneksel yöntemle tuzlu yoğurt üreten Say (2001), tuzlu yoğurtların buzdolabı ve oda sıcaklığında depolanması sirasinda fizikokimyasal, mikrobiyolojik ve duyusal özelliklerini incelemiştir. İnek ve keçi yoğurt- larından süzülmeden yapılan tuzlu yoğurtların bileşimlerini sırasıyla; $\mathrm{pH} 4.20$ ve 4.09 , titrasyon asitliği \%1.08 ve $\% 1.18$, kurumadde $\% 22.72$ ve $\% 23.27$, yağ $\% 5.52$ ve $\% 6.94$, yağsız kurumadde $\% 18.31$ ve $\% 17.68$, protein $\% 7.64$ ve $\% 8.05$, laktoz $\% 6.72$ ve $\% 5.85$, tuz $\% 3.06$ ve $\% 2.76$, tuz hariç kül $\% 0.77$ ve $\% 0.97$, uçucu yağ asiti (ml $\left.0.1 \mathrm{NaOH} 100 \mathrm{~g}^{-1}\right) 2.875$ ve 3.250 , asetaldehit (ppm) 5.68 ve 4.79 , tirozin 0.170 ve 0.228 , pihtı sikılığ 1 245.09 ve 245.25 olarak saptamıştır. Depolama süresince tuzlu yoğurtların mikrobiyolojik analiz sonuçlarına göre depolama sıcaklığının toplam aerob mezofilik bakteri, maya-küf, psikrotrof, spor oluşturan bakteri ve koliform grubu bakteri üzerine etkisinin önemli olmad1ğ ( $>0.05$ ), süzme işleminin psikrotrof bakteri ve maya-küf üzerine etkisinin önemli olduğu $p<0.05$, depolama süresinin tuzlu yoğurtların toplam aerob mezofilik bakteri, maya-küf, psikrotrof, spor oluşturan bakteri ve koliform grubu bakteri üzerine etkisinin önemli olduğu tespit edilmiştir $(\mathrm{p}<0.01)$. Tuzlu yoğurtlarda Escherichia coli'ye rastlanmamıştır.

Depolama süresinin kış yoğurdunun fizikokimyasal, mikrobiyolojik ve duyusal özelliklere etkisini inceleyen Tokatlı (2011), kış yoğurtlarında kurumadde değerlerinin \%14.70 ile 18.37, yağ değerlerinin \%5.65 ile 7.75 , protein değerlerinin $\% 3.72$ ile 4.49 , asitlik değerlerinin \%1.91 ile 2.29, $\mathrm{pH}$ değerlerinin 3.74 ile 3.90, kül değerlerinin \%0.97 ile 1.10 ve su aktivitesi değerlerinin ise 0.93-0.98 arasında değiştiğini saptamıştır. Kış yoğurtlarının hiçbirinde küf üremesi, koliform bakteri, lipolitik bakteri ve $S$. aureus tespit edilemediği saptanmıştır. 
Hatay'da geleneksel olarak üretilen tuzlu yoğurtların aroma profillerini araştıran Kaypak (2007), tuzlu yoğurt örneklerinde 60'1n üzerinde uçucu bileşen bulunduğunu ve bunların 41 tanesinin (5 keton, 6 aldehit, 4 ester, 9 alkol, 4 lakton, 12 serbest yağ asiti ve 1 diğer) potansiyel olarak tuzlu yoğurdun aromasına katkıda bulunabileceğini tespit etmiştir.

Tuzlu yoğurt mineral madde açısından değerlendirildiğinde ise $2134 \mathrm{ppm}$ Kalsiyum (Ca), 1 508 ppm Fosfor (P), 838 ppm Magnezyum (Mg), 554 ppm Potasyum (K) ve 5147 ppm Sodyum (Na) içerdiği saptanmıştır (Güler, 2007). Aynı çalışmada tuzlu yoğurdun farklı oranlarda ağır metal içeriğine sahip olduğu tespit edilmiştir.

Şahan ve Say (2003), süzme ve normal yogurdun değişik pişirme sürelerinin tuzlu yoğurdun kalitesi üzerine etkisi araştırmıştır. Araştırıcılar, 30 dakika boyunca pişirilerek elde edilen normal yoğurdun diğer pişirme süreleri uygulananlara nazaran daha fazla beğenildiğini bildirmişlerdir. 30 dakika pişirilerek elde edilen tuzlu yoğurdun asit-

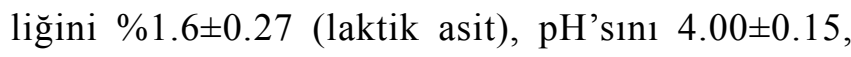
kurumaddesini $\% 21.36 \pm 0.56$, yağını $\% 2.7 \pm 0.46$, yağs1z kurumaddesini $\% 18.66 \pm 1.02$, proteinini $\% 7.30 \pm 1.21$, laktozunu $\% 7.05 \pm 0.45$, tuzunu $\% 2.58 \pm 0.09$ ve randımanını $\% 41.98 \pm 2.27$ olarak bildirmektedirler.

Yapay yolla iki farklı düzeyde $(0.05 \mu \mathrm{g} \mathrm{L-1}$ ve $0.1 \mu \mathrm{g} \mathrm{L}-1)$ aflatoksin M1 ile kontamine edilmiş sütlerden tuzlu yoğurt üreterek; bu yoğurtların üretimi ve depolanması süresince Aflatoksin M1 konsantrasyonundaki değişiklikler ile bazı kimyasal özelliklerini inceleyen Albay ve Şimşek (2012), üretilen tuzlu yoğurtların $\mathrm{pH}$, laktik asit cinsinden titrasyon asitliği, kurumadde, yağ, kurumadde de yağ, kül, tuz ve protein analiz sonuçlarını sırasıyla 3.919-3.824, \%0.946-0.921, \%30.143-30.691, \%10.115-10.115, $\% 33.557-32.957, \% 2.657-2.444, \% 1.482-1.470$ ve $\%$ 10.544-10.830 değerleri arasında belirlemişlerdir. Ayrıca tuzlu yoğurtlara uygulanan depolama işleminin (90 gün), tuzlu yoğurdun aflatoksin M1 içeriğini \%24.44 ve \%38.64 (0.05 $\mu \mathrm{g} \mathrm{L-1}$ ve $0.1 \mu \mathrm{g} \mathrm{L}-1)$ düzeyinde azalttığını tespit etmişlerdir.
Keçi sütünden üretilen tuzlu yoğurtların kimyasal ve renk özelliklerini inceleyen Güler ve Park (2009), toplam kurumaddeyi \%31.90, yağ $\% 10.20$, külü \%2.26, tuzu \%2.32, pH'y1 3.77, renk indeksi olan L değerini 92.07, a değerini -2.19 ve b değerini 14.72 olarak belirlemişlerdir.

Depolama sicaklıkları $4{ }^{\circ} \mathrm{C}$ ve $22^{\circ} \mathrm{C}$ olan yogurt ve tuzlu yoğurtta, toplam maya-küf ve Escherichia coli $\mathrm{O} 157: \mathrm{H} 7$ gelişimini inceleyen Evrendilek (2007), $22{ }^{\circ} \mathrm{C}$ ' deki toplam maya-küf sayısının $4{ }^{\circ} \mathrm{C}$ 'deki örneklerden daha yüksek olduğunu bulmuştur. Escherichia coli $\mathrm{O} 157: \mathrm{H} 7$ hem $4{ }^{\circ} \mathrm{C}$ 'de hem de $22{ }^{\circ} \mathrm{C}$ ' de gelişmiştir, ancak $4{ }^{\circ} \mathrm{C}$ 'deki gelişimi $22{ }^{\circ} \mathrm{C}$ ' deki gelişiminden daha düşüktür. Ayrıca üretilen tuzlu yoğurdun bileşimi (\% olarak); kuru madde 19.6, yağ 2.3 , protein 7.1 , kül 1.4 ve $\mathrm{pH} 3.44$ olarak tespit edilmiştir.

Depolama süresinin ve üretim yöntemlerinin kış yoğurdu örnekleri üzerine etkilerini belirlemek amacıyla yapılan bir çalışmada, örneklerin duyusal ve reolojik özellikleri ile renk değerleri arasındaki farkın önemli, fizikokimyasal özellikleri arasındaki farkların önemsiz olduğu tespit edilmiştir. Özellikle hammadde olarak tamamen keçi sütünün kullanıld1ğ1 kış yoğurtlarının daha çok beğenildiği saptanmıştır (Kesenkaş ve ark., 2017)

\section{SONUÇ}

Ülkemizde teknolojik koşullarda işlenip standart bir ürün halinde tüketiciye sunulan geleneksel yoğurt çeşidi oldukça sınırlıdır. Ayrıca henüz tanınmayan yöresel yoğurtlarda fazla miktarda üretilmektedir. Nitekim kış yoğurdunun ülkemizde üretimi; yaygın olarak kapalı aile ekonomisi içinde ve küçük işletmelerde gerçekleştirilmektedir. Dolayısıyla, standart bir üretim ve bileşimden söz etmek oldukça zordur. Kış yoğurdu üzerine yapılan çalışma sayısı da oldukça azdır. Bu alanda yapılacak bilimsel çalışmalarla hem küçük yörelerde farklı tekniklerle üretilen ve depolanan yöresel yoğurtlarımız literatüre kazandırılacak, hem de çalışmaların ileriki basamaklarında bu ürünlerin standart işleme tekniklerine sahip olması sağlanacaktır. Bu çalışmaların toplamı ülkemizin lezzet çeşitliliği anlamında büyük değer taşımaktadır. 


\section{KAYNAKLAR}

Albay Z, Şimşek B, 2012. Tuzlu yoğurtların üretimi ve depolanması sırasında aflatoksin $\mathrm{m} 1$ konsantrasyonundaki değişiklikler. III. Geleneksel Gidalar Sempozyumu, 10-12 Mayıs 2012, Konya.

Anonim, 2009. Türk Gida Kodeksi Fermente Süt Ürünleri Tebliği. $2009 / 25$.

Anonymous, 2013, The NutriJournal Latest News on Health and Food, Global Yoghurt Consumption Per Capita And Per Year. December 30.2013.http://nutrijournal.danone.com/en/articles/ stories/global-yoghurt-consumption-percapita-and-per-year/ (Erişim tarihi:11.01.2018).

Eren O, 2002. Farklı Oranlarda İnek/Keçi Sütü Karışımından Üretilen Tuzlu Yoğurtların Bazı Özelliklerinin Belirlenmesi. Harran Üniversitesi Fen Bilimleri Enstitüsü, (Basılmamış) Yüksek lisans tezi, Şanlıurfa.

Evrendilek GA, 2007. Survival of Escherichia coli O157:H7 in yoghurt drink, plain yoghurt and salted (Tuzlu) yoghurt: Effects of storage time, temperature, background flora and product characteristics. International Journal of Dairy Technology, 60(2): 118-122.

Gökalpay S, 1965. Antakya'da Konserve Yoğurtçuluk Üzerinde İncelemeler. Ankara Üniversitesi Ziraat Fakültesi, (Basılmamış) Mezuniyet tezi, Ankara.

Gönç S, 1989. Yoğurt teknolojisi ve kalite kontrolü ekşime hatası, etkisi ve alınacak önlemler. MPM Yayın No:394, Ulusal Süt ve Süt Ürünleri Sempozyumu. Ankara.

Gönç S, Oktar E, 1973. Hatay bölgesinde üretilen kış yoğurdunun teknolojisi ve kimyasal bileşimi üzerine araştırmalar. E.Ü. Ziraat Fakültesi Dergisi, 10 (1): 97-110.

Güler Z, 2007. Levels of 24 minerals in local goat milk, its strained yoghurt and salted yoghurt (tuzlu yoğurt). Small Ruminant Research, 71:130-137.

Güler Z, Park YW, 2009. Evaluatıon of chemical and color index characteristics of goat milk, its yoghurt and salted yoghurt. Tropical and Subtropical Agroecosystems, 11: $37-39$.

Güven M, Karaca OB, 2009. Van ve Şırnak illerinden temin edilen kurutulmuş yoğurtların (Kurut) bileşim özellikleri. Gıda, 34 (6):367-372.

İnal T, 1990. Süt ve Süt Ürünleri Hijyen Teknolojisi. İstanbul, Sayfa 523-559.

Kaypak D, 2007. Hatay ilinde geleneksel olarak üretilen tuzlu yogurtların aroma profillerinin tentatif olarak belirlenmesi. Mustafa Kemal Üniversitesi Fen Bilimleri Enstitüsü, (Basılmamış) Yüksek lisans tezi, Antakya.

Kesenkaş H, Karagözlü C, Yerlikaya O, Özer E, Akpınar A, Akbulut $\mathrm{N}, 2017$. Physicochemical and sensory characteristics of winter yoghurt produced from mixtures of cow's and goat's milk. Tarım Bilimleri Dergisi, 23: 53-62.

Kırdar S, Gün İ, 2000. Burdur'da üretilen süzme yoğurtlarının kalite kriterleri üzerine bir araştırma. S.D.Ü. Fen Bilimleri Enstitü Dergisi 4(1): 103-110.

Köse Ş, 2009. Depolama Süresi Boyunca Kış Yoğurtlarında Meydana Gelen Değişiklikler. Y.Y.Ü Fen Bilimleri Enstitüsü, (Basılmamış) Yüksek lisans tezi, Van.
Ocak E, 1996. Van ve Yöresinde Üretilen Kış Yoğurtlarının Duyusal, Mikrobiyolojik, Fiziksel ve Kimyasal Nitelikleri Üzerine Bir Araştırma. Y.Y.Ü Fen Bilimleri Enstitüsü, (Basılmamış) Yüksek lisans tezi, Van.

Ocak E, Akyüz N, 1998. Van ve yöresinde üretilen kış yoğurtlar1nın duyusal, mikrobiyolojik ve kimyasal nitelikleri üzerine bir araştırma. V. Süt ve Süt Ürünleri Sempozyumu, 21-22 Mayıs 1998, Tekirdağ.

Özdemir S, Gökalp HY, Zorba Ö, 1995. Yoğurdun Muhafaza Teknikleri, Milli Prodüktivite Merkezi Yayın No:548, 166-177.

Özrenk E, 2004. Kurutulmuş ve koyulaştırılmış yoğurtlar. Geleneksel Gidalar Sempozyumu, 23-24 Eylül 2004, Van.

Sakız Ü, 1973. Genel ve özel sütçülük. 2.Baskı. Haşmet Basımevi, İstanbul. $287 \mathrm{~s}$.

Say D, 2001. İnek ve keçi sütlerinden üretilen tuzlu yoğurtların özellikleri ve bu özelliklere depolama koşullarının etkisi. Çukurova Üniversitesi Fen Bilimleri Enstitüsü, (Basılmamış) Yüksek lisans tezi, Adana.

Şahan N, Say D, 1998. Hatay ilinde üretilen tuzlu yoğurtlar üzerine bir araştırma. Geleneksel süt ürünleri, Milli Prodüktivite Merkezi Yayınları No:621, V. Süt ve Süt Ürünleri Sempozyumu, 21-22 Mayıs 1998, Tekirdağ.

Şahan N, Say D, 2003. Tuzlu yoğurt üretimi üzerine bir araştırma. Gida, 28(5):545-551.

Uysal S, 1993. Vakum ve ultrafiltrasyonla koyulaştırılan sütlerden torba yoğurt yapımı ve klasik yöntemle karşılaştırılması üzerine araştırmalar. Ege Üniversitesi Fen Bilimleri Enstitüsü, (Basılmamış) Doktora tezi, İzmir.

Van Den Berg JCT, 1988. Dairy Technology in the Tropics and Subtropics. Pudoc, Wageningen.

Tokatlı F, Sağdıç O, Göncü A, 2012. Karamanda Üretilen Geleneksel Kış yoğurdu. III. Geleneksel Gıdalar Sempozyumu, 10-12 Mayıs 2012, Konya.

Tokatlı F, 2011. Geleneksel Olarak Üretilen kış yoğurdunun fizikokimyasal, mikrobiyolojik ve duyusal özellikleri üzerine depolamanın etkisi. Erciyes Üniversitesi Fen Bilimleri Enstitüsü, (Basılmamış) Yüksek lisans tezi, Kayseri.

Türkoğlu H, Atasoy F, Özer B, 2003. Şanlıurfa ilinde üretilen ve satışa sunulan süt, yoğurt ve urfa peynirlerinin bazı kimyasal özellikleri. Harran Üniversitesi Ziraat Fakültesi Dergisi, 7(34): 69-76.

Yaygın H, 1970. Tulum yoğurdu. E.Ü. Ziraat Fakültesi Dergisi, 7 (2): 25-34.

Yaygın H, 1993. Süt Sanayi Yatırımlarına Yönelik Tesvikler. 5. Türkiye Sütçülük Kongresi. TMMOB Ziraat Mühendisleri odası ve Ankara Üniversitesi Ziraat Fakültesi, 218 s.

Yöney Z, 1967. Yoğurt Teknolojisi. A.Ü. Zir. Fak. Yayınları:289, A.Ü. Basımevi, Ankara, $103 \mathrm{~s}$.

Yöney Z, 1974. Süt Kimyası. Ankara Üniv. Yayınları. No:530, D.K. 175. Ankara Üniversitesi Basımevi, Ankara, 218 s. 